\title{
Enrichment and identification of glycoproteins in human saliva using lectin magnetic bead arrays.
}

3

4 Michael Caragata ${ }^{1}$, Alok K. Shah ${ }^{1}$, Benjamin L. Schulz ${ }^{2}$, Michelle M. Hill ${ }^{1 *}$ Chamindie

5 Punyadeera ${ }^{3 *}$,

6 1. The University of Queensland Diamantina Institute, The University of Queensland,

7 Translational Research Institute, Woolloongabba, Queensland, Australia, 4102

8 2. The School of Chemistry and Molecular Biosciences, The University of Queensland,

9 St Lucia, Queensland, Australia, 4072.

$103 . \quad T h e$ School of Biomedical Sciences, The Institute of Biomedical Innovations,

11 Queensland University of Technology, 60 Musk Avenue, Kelvin Grove and the Translational

12 Research Institute, Woolloongabba, Queensland, Australia, 4102.

$13 *$ Correspondence:

14 Michelle Hill, The University of Queensland Diamantina Institute, The University of 15 Queensland, Translational Research Institute, 37 Kent Street, Woolloongabba, Queensland, 16 Australia, 4102 Email: m.hill2@uq.edu.au

17 Ph: +617-3443-7049 Fax: +617-3443-6966

$18 *$ Correspondence:

19 Chamindie Punyadeera, The School of Biomedical Sciences, The Institute of Biomedical 20 Innovations, Queensland University of Technology, 60 Musk Avenue, Kelvin Grove and the 21 Translational Research Institute, Woolloongabba, Queensland, Australia, 4102 Email:

22 chamindie.punyadeera@qut.edu.au

Ph: +61 (0)7- 3138 -0830 Fax: +61 (0)7-3138- 6030 


\section{Abstract:}

Aberrant glycosylation of proteins is a hallmark of tumorigenesis, and could provide 28 diagnostic value in cancer detection. Human saliva is an ideal source of glycoproteins due to 29 the relatively high proportion of glycosylated proteins in the salivary proteome. Moreover, 30 saliva collection is non-invasive, technically straightforward and the sample collection and storage is relatively easy. Although, differential glycosylation of proteins can be indicative of disease states, identification of differential glycosylation from clinical samples is not trivial. To facilitate salivary glycoprotein biomarker discovery, we optimised a method for differential glycoprotein enrichment from human saliva based on lectin magnetic bead arrays (saLeMBA). Selected lectins from distinct reactivity groups were used in the saLeMBA platform to enrich salivary glycoproteins from healthy volunteer saliva. The technical reproducibility of saLeMBA was analysed with LC-MS/MS to identify the glycosylated proteins enriched by each lectin. Our saLeMBA platform enabled robust glycoprotein enrichment in a glycoprotein- and lectin-specific manner consistent with known proteinspecific glycan profiles. We demonstrated that saLeMBA is a reliable method to enrich and detect glycoproteins present in human saliva.

*Keywords: Saliva proteomics, Biomarker discovery, Glycosylation, Lectins, Magnetic Beads

Abbreviations: LeMBA- Lectin Magnetic Bead Array; saLeMBA- Saliva optimized Lectin 


\section{Introduction:}

Glycosylation, the covalent addition of sugars to proteins, is a common post-translational modification (PTM) with more than $50 \%$ of all eukaryotic proteins thought to be glycosylated [1]. Glycoproteins and glycosylation play fundamental roles in many biological processes and have important cellular functions such as increasing protein stability, protecting proteins from degradation, increasing protein solubility and regulating protein activity [2]. Glycosylation is also known to be organism, tissue and cell type specific, regulated by the quantity and localization of glycosyltransferases enzyme and the available amount of substrate [3]. However, the equilibrium of this relationship can be disrupted in a disease state. Glycosylation is known to change within a cell from "healthy" to a "disease" state [4]. For instance, aberrant glycosylation is associated with cancer progression in breast [5], prostate [6], ovarian [7], lung [8] and hepatocellular carcinoma (HCC) [9].

Human saliva is emerging as a promising biological fluid for diagnostic testing. There is $20-30 \%$ overlap in protein content between saliva and blood/plasma, suggesting that saliva could be an attractive fluid for biomarker discovery for systemic diseases and may serve as a diagnostic alternative to blood tests [10]. Compared to other body fluids such as blood, cerebral spinal fluid (CSF) and urine, the collection of whole saliva is easy and relatively stress-free for the person donating it, non-invasive, and simple. As such it allows collection of multiple samples at one time without imposing too much discomfort, is relatively safe for hospital staff to handle, and is cost-effective [11, 12]. Saliva has been proposed as a diagnostic medium to detect many systemic diseases [13] such as breast cancers, lung cancers, pancreatic cancers [14], Sjögren's syndrome [15], heart failure [16], and head and neck squamous cell carcinomas $[17,18]$.

While glycosylation is critical for modulating protein activity, efficient and sensitive analysis of protein glycosylation frequently requires enrichment of glycoproteins or glycopeptides. Current methods for glycoprotein enrichment include hydrazide chemistry [19-21], hexapeptide libraries [22], magnetic nano-probes [23], phenylboronic acid [24] and lectin based techniques including single lectin affinity chromatography, multiple lectin affinity chromatography [25], lectin microarrays [26], and lectin magnetic bead arrays [27, 28]. Lectins recognize specific glycan structures with high specificity and affinity, allowing targeted enrichment of proteins modified with specific subclasses of glycans. Methods such as single/multiple and serial lectin affinity chromatography can greatly reduce the complexity 
of the sample being analysed, while simultaneously enriching for specific glycosylation structures of interest. However, the use of lectins for glycoprotein enrichment has drawbacks. The process can be time consuming, lectin affinity chromatography methods are not suitable for large population based screening studies, and no single lectin has the ability to enrich the entire glycoproteome within a biological sample [25, 29, 30]. Previously, we have reported $[27,28]$ the development of lectin magnetic bead arrays (LeMBA) for efficient highthroughput glycoprotein enrichment in serum samples using a panel of lectins.

In the present study, we have optimised and developed the LeMBA methodology for use with complex biological matrices with relatively higher viscoelastic properties such as human saliva (saLeMBA). We describe an optimised protocol for saliva collection and processing, and demonstrate that the saLeMBA technology platform is robust, reproducible and can identify protein-specific differences in glycan structures in human saliva. We anticipate that saLeMBA will be useful in identifying modifications in human salivary glycoproteins, opening up new avenues of research in the field of salivary glycoproteomics.

\section{Methods:}

\subsection{Study design:}

This study was approved by the University of Queensland Medical Ethical Institutional Board and the Queensland University of Technology Ethics Committee (QUT 1400000617). We recruited 4 healthy, non-smoker volunteers, less than 30 years of age with no underlying medical conditions. Signed informed consent was obtained before saliva sample collection.

\subsection{Saliva sample collection and processing:}

Volunteers were requested not to eat food or drink (except water) for $1 \mathrm{~h}$ prior to donating saliva, adhering to our previously published saliva collection protocols [12, 31]. We asked the volunteers to rinse their mouths to remove any food debris, and then collected unstimulated whole mouth saliva as previously described [32]. In brief, unstimulated saliva was collected by asking volunteers to tilt their heads down and pool saliva in the front of their mouth for $2 \mathrm{~min}$ before the saliva sample was expectorated into a $50 \mathrm{~mL}$ Falcon Tube kept on ice. The saliva was then clarified at $500 \mathrm{rcf}$ for $10 \mathrm{~min}$ at $4^{\circ} \mathrm{C}$ to remove cellular debris, and the supernatant was aliquoted into separate protein LoBind tubes (Eppendorf, Hamburg, Germany). All samples were stored at $-80^{\circ} \mathrm{C}$ until required. Serum was obtained from whole 
119 blood by centrifuging at $500 \mathrm{rcf}$ for $15 \mathrm{~min}$ at $24^{\circ} \mathrm{C}$. Samples were stored at $-80^{\circ} \mathrm{C}$ until 120 analysis.

Dynabeads ${ }^{\circledR}$ MyOne ${ }^{\mathrm{TM}}$ Tosylactivated were purchased from Life Technologies (Carlsbad, CA, USA). Lectins: Aleuria aurantia (AAL), Bauhinia purpurea lectin (BPL), Jacalin (JAC), Soybean agglutinin (SBA), Narcissus pesudonarcissus lectin (NPL) and Sambucus nigra agglutinin (SNA) were purchased from Vector Laboratories (Burlingame, CA, USA) while lectins Concanavalin A (ConA) and Erythrina cristagalli (ECA) were purchased from Sigma. Bradford assay kit, Triton X-100, 30\%-bis acrylamide, 5 x Laemmli sample buffer and TEMED were purchased from Bio-Rad (Hercules, CA, USA). All other chemicals were obtained from Sigma. PAGE

Coupling of lectins to Dynabeads ${ }^{\circledR}$ MyOne ${ }^{\mathrm{TM}}$ Tosylactivated was performed according to previously established methods [27-29]. Saliva (50 $\mu \mathrm{g}$ of total protein, and typically a protein concentration of $1-2 \mu \mathrm{g} / \mu \mathrm{L}$ ) was added to denaturing buffer (final concentration $20 \mathrm{mM}$ Tris-HCl buffer $\mathrm{pH} 7.4,1 \%$ SDS, 5\% Triton $\mathrm{x}-100$, and $20 \mathrm{mM}$ DTT) to give a final volume of $75 \mu \mathrm{L}$, and incubated at $65^{\circ} \mathrm{C}$ for $30 \mathrm{~min}$. Reduced cysteines in the denatured samples were alkylated by addition of iodoacetamide to a final concentration of $100 \mathrm{mM}$ and incubated in the dark for $30 \mathrm{~min}$. Reduced/alkylated saliva was diluted with $1425 \mu \mathrm{L}$ of binding buffer $(20 \mathrm{mM}$ Tris- $\mathrm{HCl}$ buffer $\mathrm{pH} 7.4,300 \mathrm{mM} \mathrm{NaCl}, 1 \mathrm{mM} \mathrm{CaCl}, 1$ $\mathrm{mM} \mathrm{MnCl} 2,1 \%$ Triton X-100, 1 x Protease inhibitor cocktail) and incubated with $50 \mu \mathrm{L}$ of lectin-coupled magnetic beads for $1 \mathrm{~h}$ at $4^{\circ} \mathrm{C}$ with constant rotation. The beads with captured salivary glycoproteins were washed 3 times in washing buffer $(20 \mathrm{mM}$ Tris- $\mathrm{HCl}$ buffer $\mathrm{pH}$ 7.4, 0.05\% SDS, $1 \mathrm{mM}$ DTT , $300 \mathrm{mM} \mathrm{NaCl} 1 \mathrm{mM} \mathrm{CaCl}_{2}, 1 \mathrm{mM} \mathrm{MnCl}_{2}, 1 \%$ Triton X-100). For initial analysis and optimisation of saLeMBA, salivary glycoproteins were eluted from the beads by resuspending them in $20 \mu \mathrm{L}$ of $2 \mathrm{x}$ Laemmli sample buffer and incubating at 95 ${ }^{\circ} \mathrm{C}$ for $10 \mathrm{~min}$. Eluted proteins were then separated by SDS-PAGE using hand-cast $1.0 \mathrm{~mm}$ thick 15\% polyacrylamide gels using a Bio-Rad Mini-PROTEAN quad 4 system. The gels were electrophoresed at a constant $100 \mathrm{~V}$ until the bromophenol blue reached the bottom of the gel and stained overnight in colloidal Coomassie G-250 [33]. Gels were then de-stained in 
$1501 \%$ glacial acetic acid until background colour was completely removed. Gels were scanned and protein bands were quantified using Image J (National Institute of Mental Health, Bethesda, Maryland, USA).

For the identification of captured salivary glycoproteins, beads were washed 7 times with $20 \mu \mathrm{L}$ of $50 \mathrm{mM}$ ammonium bicarbonate $(\mathrm{ABC})$, resuspended in $20 \mu \mathrm{L}$ of $50 \mathrm{mM} \mathrm{ABC}$ with $1 \mu \mathrm{g}$ trypsin (Promega, Madison, WI, USA) and incubated at $37{ }^{\circ} \mathrm{C}$ for $16 \mathrm{~h}$ with constant rotation. The supernatant was removed and kept and the beads were washed in 20 $\mu \mathrm{L}$ of $50 \mathrm{mM} \mathrm{ABC}$, before combining supernatants of digested peptides. Peptide samples were transferred to u-bottom microtitre plates (Greiner Bio-One, Kremsmünster, Austria), dried in a speed vacuum at $45^{\circ} \mathrm{C}$ for $\sim 1 \mathrm{~h}$ and stored at $-80^{\circ} \mathrm{C}$ until further use.

For LC-MS/MS, samples were resuspended in $20 \mu \mathrm{L}$ of $0.1 \% \mathrm{v} / \mathrm{v}$ formic acid. Digested peptides were detected using a 6520 QTOF (Agilent, Santa Clara, CA, USA) coupled with a Chip Cube and 1200 HPLC (Agilent). The nano pump was set at $0.3 \mu \mathrm{L} / \mathrm{min}$ and the capillary pump at $2.5 \mu \mathrm{L} / \mathrm{min}$. The HPLC-chip used in this study contained a $160 \mathrm{~nL}$ C18 trapping column, and $150 \mathrm{~mm} \mathrm{C18}$ analytical column (Agilent, USA). Buffer A was 0.1 $\% \mathrm{v} / \mathrm{v}$ formic acid and Buffer B was $90 \% \mathrm{v} / \mathrm{v}$ acetonitrile containing $0.1 \% \mathrm{v} / \mathrm{v}$ formic acid. Peptides were eluted from the column using a gradient from $6 \% \mathrm{~B}$ at $0 \mathrm{~min}$ to $46 \% \mathrm{~B}$ at 45 min. Nano pump \% B was increased to $95 \%$ B at $45.5 \mathrm{~min}$, maintained at that level till 53.5 min, and decreased to the original $6 \% \mathrm{~B}$ at $55.5 \mathrm{~min}$, with a total acquisition time of $60 \mathrm{~min}$. The mass spectrometer was operated in a $2 \mathrm{GHz}$ extended dynamic range and programmed to acquire 9 precursor MS1 spectra per second and $4 \mathrm{MS} / \mathrm{MS}$ spectra for each MS1 spectra. Dynamic exclusion applied after $2 \mathrm{MS} / \mathrm{MS}$ within $0.15 \mathrm{~min}$. In addition, exclusion for lectin peptides was applied as reported previously [28].

Identification of peptides and proteins was achieved using Spectrum Mill (Agilent B.04.00.127) with Swiss-Prot human database (3/1/2012). A maximum of 2 missed cleavages was allowed, precursor mass tolerance was set at $20 \mathrm{ppm}$, and product mass tolerance was set at $50 \mathrm{ppm}$. Carbamidomethylation (C) was selected as a fixed modification and oxidized methionine was selected as a variable modification. Default settings were used for the automatic validation of the identified proteins and peptides. Results were then filtered with

180 the following settings: protein score $>15$, peptide score $>6$ and $\%$ scored peak intensity $(\%$ SPI $>60)$. False discovery rate was set to $1 \%$. 


\section{Results and Discussion}

\subsection{Development of saLeMBA methodology to use with human saliva}

Previously, LeMBA [27, 28] has been used for glycoprotein enrichment from serum.

We optimized various parameters of this previously published LeMBA methodology to enrich salivary glycoproteins. Human saliva is a viscoelastic biofluid and contains an unusually high proportion of glycoproteins with very unusual complex carbohydrate structures. A key feature of saliva is that it has a much lower protein concentration than blood, which necessitated a larger volume of binding buffer. To determine whether the low concentrations of proteins in saliva affected the efficiency of glycoprotein enrichment by lectin-coupled beads, we enriched glycoproteins from serum containing $50 \mu \mathrm{g}$ of total protein using the standard LeMBA method, and a simulated saLeMBA method in which the total incubation volume was increased to $1.5 \mathrm{~mL}$ to mimic the protein concentration in whole mouth unstimulated saliva, (labelled as diluted LeMBA in Figure 1A). SDS-PAGE analysis of eluted glycoproteins showed minimal differences between these treatments (Figure. 1A) indicating that the dilution effect of the larger binding buffer volume used in the saLeMBA methodology has no discernible influence on the efficiency of glycoprotein enrichment. As more dilute protein concentrations may affect the kinetics of glycoprotein-lectin interactions, we next investigated the optimal time for incubating saliva samples with ConA coupled beads using the saLeMBA methodology. This demonstrated that there are no significant changes in the intensity of eluted glycoproteins with varying incubation times (Figure. 1B). Therefore, an incubation time of $1 \mathrm{~h}$ was used for all subsequent experiments, consistent with the previously published LeMBA methodology $[27,28]$. To determine the optimum amount of salivary protein to use with lectin-coupled beads, we applied different protein amounts of saliva consisting of $25-100 \mu \mathrm{g}$ of total protein to $50 \mu \mathrm{g}$ beads coupled with JAC, WGA, and ConA lectins. These lectins were selected based on their distinct and diverse carbohydratebinding specificities (Table 1).

Elusions from each condition were separated by SDS-PAGE and the total protein intensities were measured using Image J. For all lectins, protein intensity increased linearly up to $80 \mu \mathrm{g}$ of applied salivary protein (Figure. 1C, Figure. 1D, Figure. 1E). We therefore selected $50 \mu \mathrm{g}$ of salivary protein as a sufficient and non-saturating sample quantity. A summary of key features of the optimized saLeMBA method are shown in Table 2. 
A

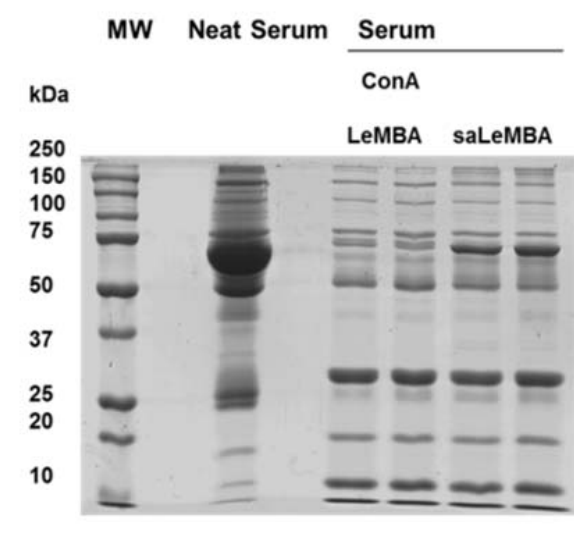

C

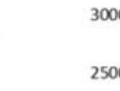

B
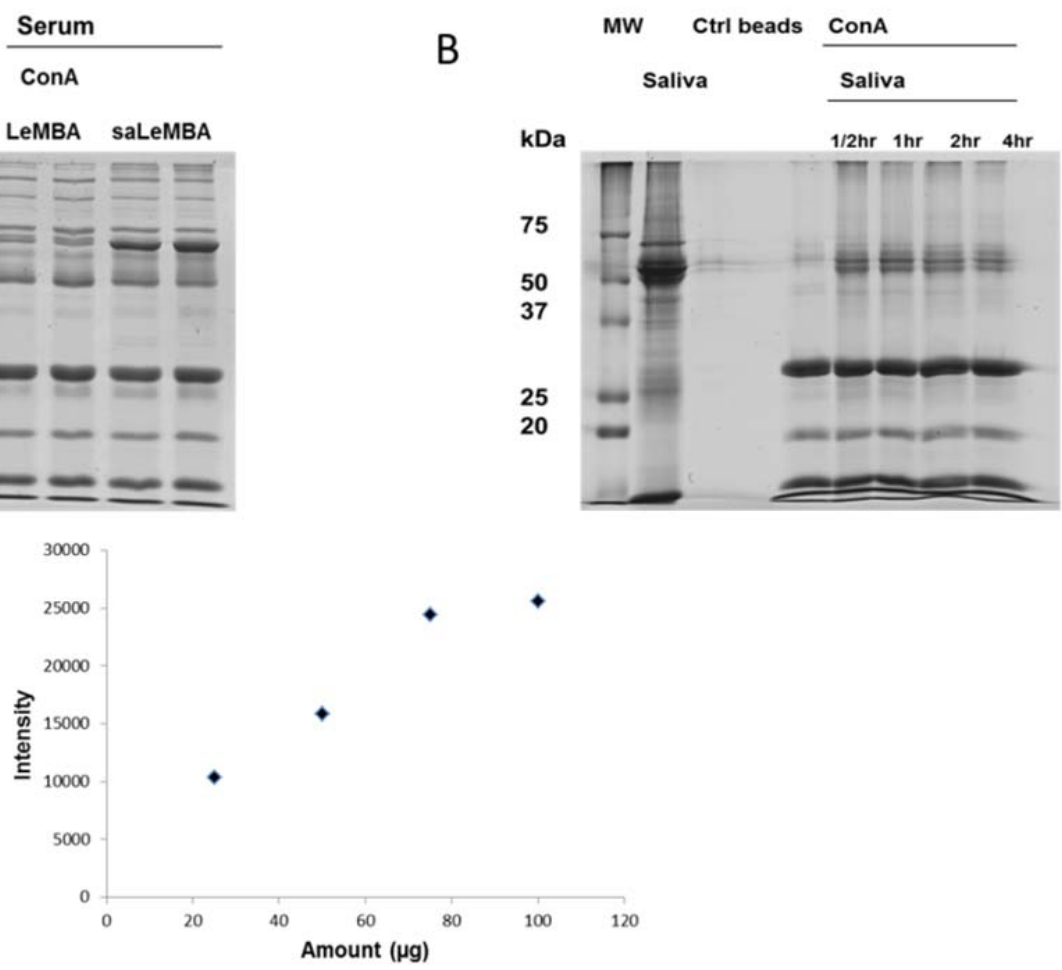

D

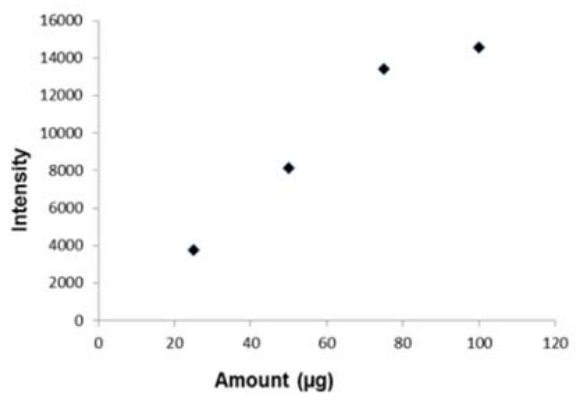

$\mathrm{E}$

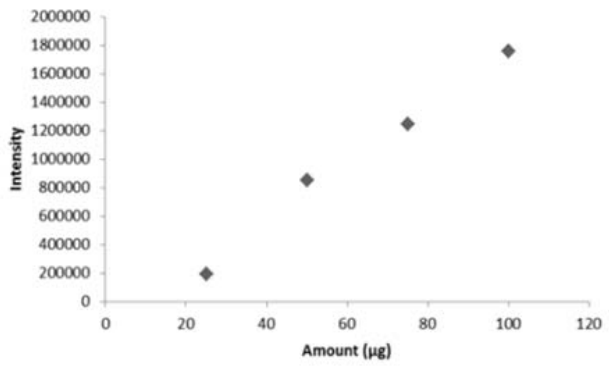

214 Figure 1: The optimization of SaLeMBA platform: (A) the comparison of LeMBA vs. the 215 diluted LeMBA methodologies using $50 \mu \mathrm{g}$ of healthy volunteer serum on ConA coupled 216 beads run on 10\% SDS-PAGE stained in colloidal Coomassie, (B) The comparison of 217 incubation times for saLeMBA. Each lectin was bound to tosyl activated magnetic beads with 218 the same amount of protein $(50 \mu \mathrm{g})$. Titration of $25 \mu \mathrm{g}-100 \mu \mathrm{g}$ unstimulated whole mouth 219 saliva using the saLeMBA method across (C) ConA coupled beads, (D) JAC coupled beads, 220 and (E) WGA coupled beads. The lectin pull downs were analysed using 10\% SDS-PAGE 221 stained in colloidal Coomassie. 
Having optimized the experimental conditions for saLeMBA, we tested the utility of this method using a panel of five lectins. Human saliva from healthy volunteers $(n=4)$ were pooled and used across 5 lectins (AAL, BPL, ECA, NPL, SNA) in three technical replicates. These five lectins were selected because of their varying glycan binding specificities, with each representing a different reactivity group: AAL (Fuc $\alpha$ 1-2, -3, -6 linked), BPL (Galß1-

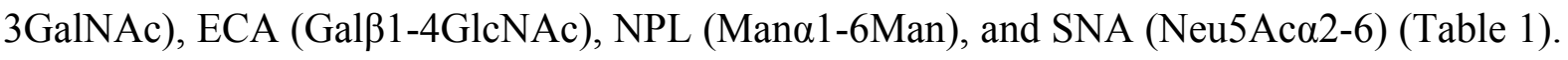
The subsequent pull down fractions were then analysed with LC-MS/MS. Supplementary Table 1 shows the protein identifications generated by Spectrum Mill for all proteins found across each replicate and lectin. Table 3 displays lectin binding distributions for proteins consistently identified across technical triplicate analyses. Approximately $70 \%$ of proteins bound across the 5 lectins were identified as glycosylated (as annotated in UniProt) and the remaining $30 \%$ of the identified proteins were not glycosylated. These non-glycosylated proteins were typically abundant salivary proteins which may account for their presence. Alternatively, these findings may suggest new sites of glycosylation on proteins which have not previously been shown to be glycosylated.

The highest number of glycoproteins were bound to AAL (46 unique proteins), followed by NPL (45 unique proteins) and SNA (31 unique proteins). Importantly, many proteins were found across more than one lectin, such as Cathepsin G, Alpha Amylase 1, Zinc Alpha 2 glycoprotein, and Zymogen granule protein 16 homolog B. This suggests these proteins (and others) are modified by multiple glycans at distinct sites. Specifically, our saLeMBA results support the prevalence of Fuc, Man and Sialic Acid modifications in human salivary glycoproteins, consistent with previous glycomic analyses which revealed these monosaccharides are present in high relative abundance in human saliva [24, 34].

Abundant salivary proteins such as Alpha-1-amylase and Zymogen granule protein 16 homolog-B were also found across all five lectins. In contrast, proteins such as Azurocidin (AAL), Haptoglobin (SNA), and Myeloperoxidase (NPL) were found specific to their respective lectins. In agreement with binding to the Fucose-specific AAL, Azurocidin (or Heparin binding protein) is an N-linked glycoprotein with abundant truncated neutral glycans with core fucosylation (Fucal-6GlcNAc) [35]. Haptoglobin, an N-linked glycoprotein, has been reported to carry complex glycan structures with extensive $\alpha 2-6$ and some $\alpha 2-3$ linked sialic acid [36], consistent with our identification of Haptoglobin after SNA enrichment specific for Neu5Aca2-6. Finally, Myeloperoxidase has been reported to be modified with 
258 high mannose glycans at five of its N-glycosylation sites [37]. Importantly, Mucin-5B was 259 absent from lectin pull down using ECA coupled beads, whilst Mucin-5B was captured on 260 AAL, BPL, NPL and SNA beads (Figure 2C). This is to be expected as Mucin-5B is 261 extensively O-glycosylated with few non-modified lactosamine motifs and extensive terminal 262 Fucose and sialic acid [34].

263

264

265

266

267

268

269

270

271 

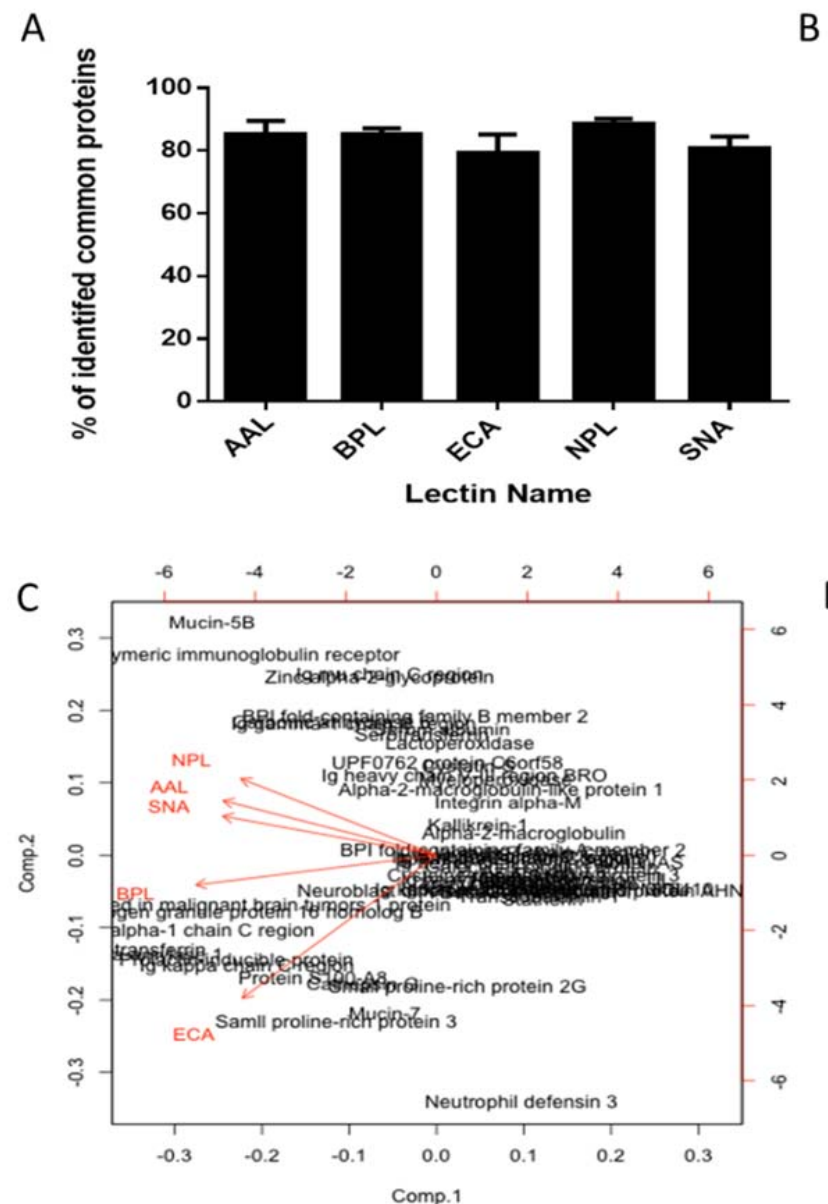

B

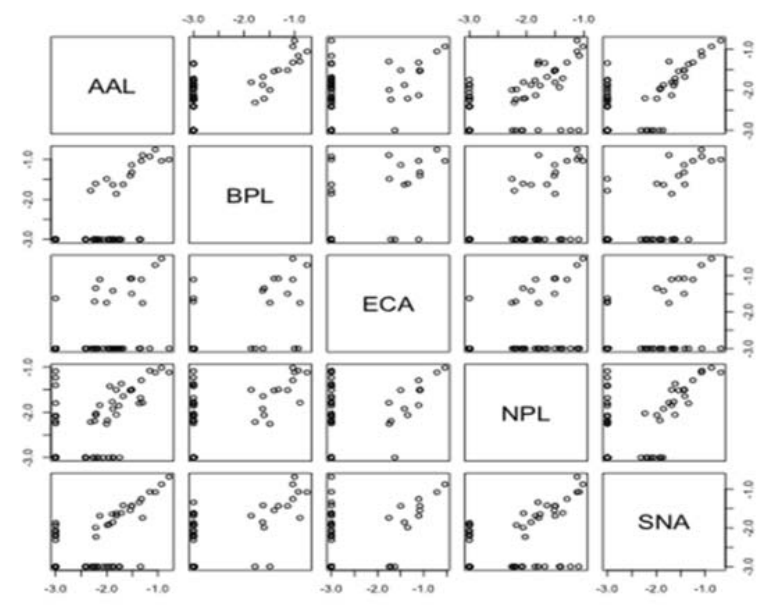

D

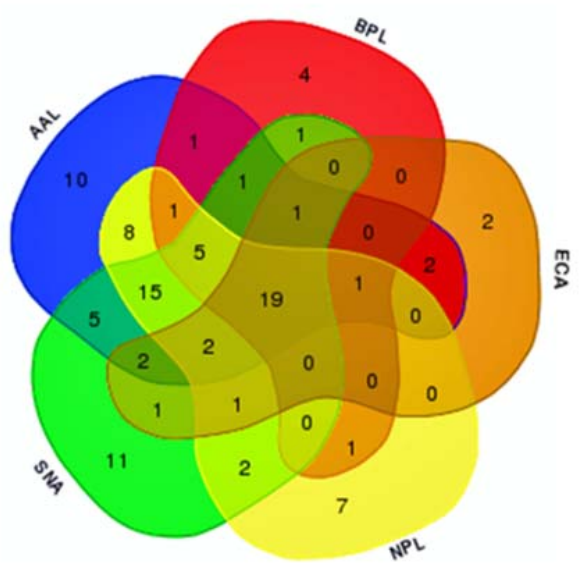

274 Figure 2: LC-MS/MS triplicate analysis of 5 lectins used in saLeMBA enrichment of pooled

275 human unstimulated whole mouth saliva. (A) Proportion of common proteins found across 3

276 replicates for each lectin (B) Correlations between intensities of common proteins determined

277 by pairwise analysis (C) PCA plot, and (D) Venn diagram showing overlap of proteins 278 identified by each lectin. 
We next investigated the technical reproducibility of saLeMBA. Technical triplicate analysis showed that the enrichment of specific glycoproteins was highly consistent, with all lectins showing at least $79 \%$ common proteins across the triplicate enrichments (Figure. 2A, Table 3). These results represent the percentage of proteins found across each of the 3 replicates for each of the 5 different lectins (AAL, BPL, ECA, NPL, and SNA). It should be noted that these results do not indicate whether the identified proteins mentioned in (Table 3) share the same/similar abundances. For example Alpha 1 amylase is found on each of the 3 replicates and with each of the 5 lectins and would be considered a common protein for our study. Pairwise analysis and PCA comparison of the Spectrum Mill protein identification scores showed that the different lectins enriched distinct subsets of the salivary glycoproteome (Figure. 2B, Figure. 2C).

Pairwise comparisons of logged normalized glycoprotein abundance (Figure. 2B), demonstrated an excellent correlation between AAL vs NPL, AAL vs SNA and NPL vs SNA. While each lectin was able to identify unique proteins (with the exception of ECA), the correlation which AAL, NPL, SNA demonstrated the reproducibility of saLeMBA. In contrast, the lack of correlation between lectins with distinct binding specificities such as ECA vs NPL highlights the strength of using multiple diverse lectins in glycoprotein enrichment analysis.

PCA comparisons of logged normalized glycoprotein abundance (Figure. 2C) supported these findings, as arrows for SNA and BPL were almost perpendicular, with the strong correlation of AAL, NPL and SNA clearly visible, as well as highlighting the glycoproteins determining these various lectin-binding specificities. Literature [28] describes NPL (binds core mannose structures) as heavily influenced by the presence of branched sugars from the binding site suggesting that although NPL recognises core Man structures the presence of other branching glycans may affect its expected binding. This demonstrates that the lectins selected for reproducibility cover a diverse range of glycan binding activity, and supports the accuracy of our saLeMBA methodology. A Venn diagram (Figure. 2D) showing the overlap of proteins identified after enrichment with each lectin. We are able to distinctly identify proteins unique to each lectin as well as proteins which are identified by all 5 lectins.

314 With reference to Figure. 2A, this qualitative analysis refers to the identification of a protein, 315 whereas the results depicted in Figure. $2 \mathrm{~B}$ and Figure.2C take into account the relative 316 abundance of a particular protein. As with Figure 2A, this qualitative analysis refers to the 317 identification of a protein, whereas the results depicted in Figure. 2B and Figure.2C take into 
318 account the relative abundance of a particular protein. Reproducible identification of 319 glycoproteins across a wide abundance range shows the robustness and specificity possible 320 with saLeMBA for the enrichment of glycoproteins in saliva. Our current method allows 321 relative quantification, which is appropriate for many discovery applications [38].

322

323

324

325

326

327

328

329

330

331 


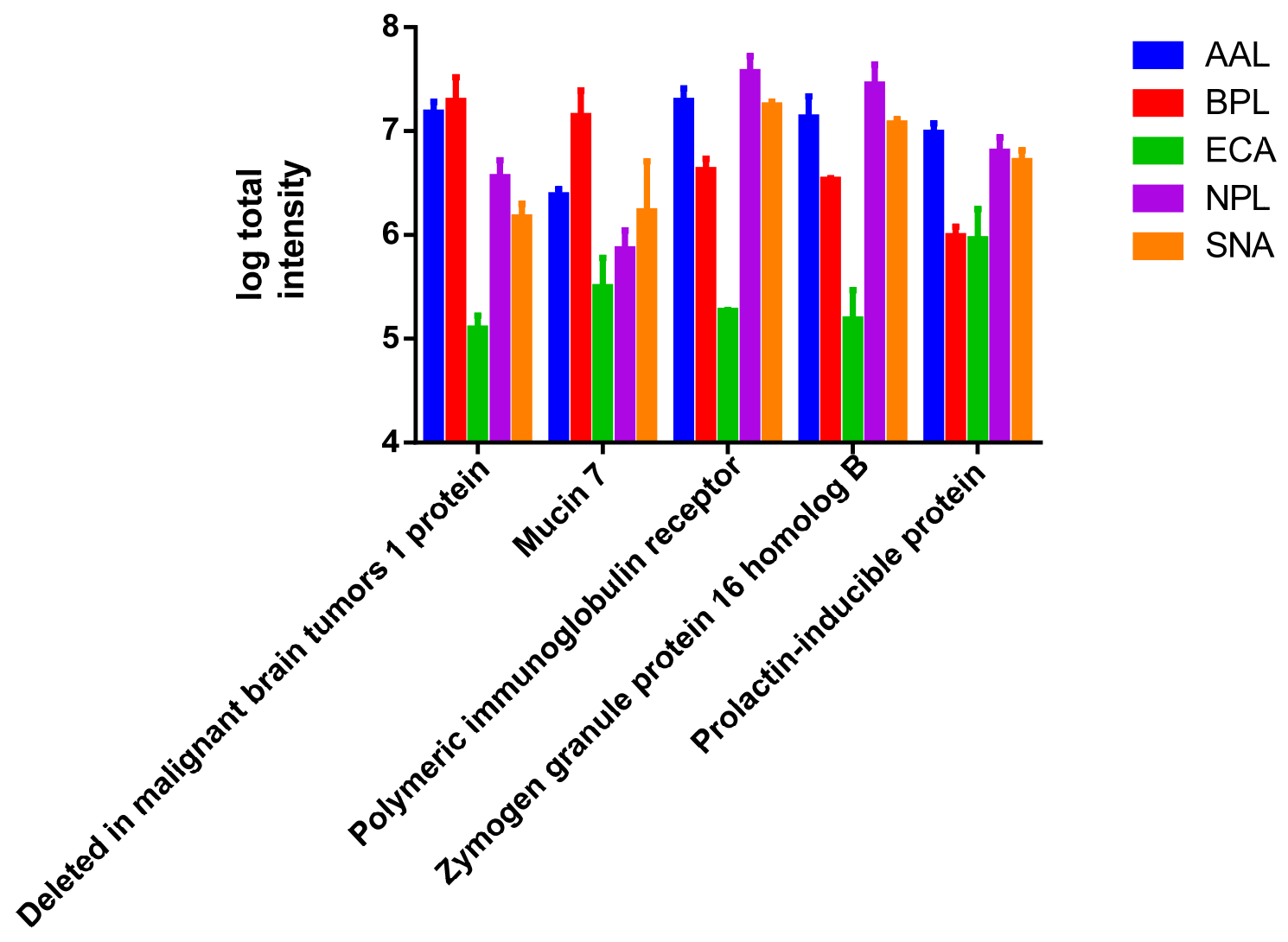

332

334

Figure 3: Abundance of selected salivary glycoproteins after saLeMBA enrichment

335 with each lectin. Intensity is measured as $\log (10)$ total intensity (determined by Spectrum

336 Mill) with bars representing the mean across the 3 repeat experiments and errors representing

337 standard deviations.

338

339

340

341

342

343

344 
345 Quantitative comparisons of the relative abundance of selected glycoproteins enriched by each lectin showed high technical reproducibility (Figure 3). For instance, Deleted in malignant brain tumors 1 protein is more abundant than Prolactin-inducible protein after enrichment by BPL, but the reverse is true after enrichment by NPL or SNA coupled beads. Reproducible identification of glycoproteins across a wide abundance range and shows the robustness and specificity possible with saLeMBA for the enrichment of glycoproteins in saliva.

\section{Conclusion}

The emergence of human saliva as a valuable diagnostic fluid for the identification and characterization of proteins and peptides involved in systemic diseases has led to the development and optimization of different techniques for their discovery. In this study, we have developed saLeMBA, a robust and reproducible methodology to enrich salivary glycoproteins based on differential lectin binding. We suggest our optimised saLeMBA may be useful in screening for potential glycoprotein biomarkers in human saliva to discern glycosylation changes that are specific for diseases.

\section{Supporting Information}

361 Table S1 shows the MS data generated for the reproducibility testing of saLeMBA (triplicate 362 experiment using 5 different lectins).

\section{Acknowledgments:}

This study was supported by the Queensland Centre for Head and Neck Cancer funded by Atlantic Philanthropies, the Queensland Government, and the Princess Alexandra Hospital. In addition, we acknowledge the financial support from the Queensland University of Technology VC's start-up funds for Chamindie Punyadeera. M.M.H. is supported by an Australian Research Council Future Fellowship (FT120100251). B.L.S. is supported by a National Health and Medical Research Council Career Development Fellowship (APP1087975). A.K.S. is a recipient of International Postgraduate Research Scholarship and The University of Queensland Centennial Scholarship. 
376 [1] M. Sondej, P.A. Denny, Y. Xie, P. Ramachandran, Y. Si, J. Takashima, W. Shi, D.T. 377 Wong, J.A. Loo, P.C. Denny, Glycoprofiling of the Human Salivary Proteome, Clinical 378 proteomics, 5 (2009) 52-68.

379 [2] P.M. Rudd, T. Elliott, P. Cresswell, I.A. Wilson, R.A. Dwek, Glycosylation and the 380 Immune System, Science, 291 (2001) 2370-2376.

381 [3] K. Chandler, R. Goldman, Glycoprotein Disease Markers and Single Protein-omics, 382 Molecular \& Cellular Proteomics, 12 (2013) 836-845. [4] P.M. Drake, W. Cho, B. Li, A. Prakobphol, E. Johansen, N.L. Anderson, F.E. Regnier, B.W. Gibson, S.J. Fisher, Sweetening the Pot: Adding Glycosylation to the Biomarker Discovery Equation, Clinical Chemistry, 56 (2010) 223-236.

386 [5] L.Y. Lee, M. Thaysen-Andersen, M.S. Baker, N.H. Packer, W.S. Hancock, S. Fanayan, 387 Comprehensive N-glycome profiling of cultured human epithelial breast cells identifies unique secretome $\mathrm{N}$-glycosylation signatures enabling tumorigenic subtype classification, $\mathrm{J}$ Proteome Res, 13 (2014) 4783-4795.

390 [6] E. Song, A. Mayampurath, C.Y. Yu, H. Tang, Y. Mechref, Glycoproteomics: identifying the glycosylation of prostate specific antigen at normal and high isoelectric points by LCMS/MS, J Proteome Res, 13 (2014) 5570-5580. [7] K. Chen, A. Gentry-Maharaj, M. Burnell, C. Steentoft, L. Marcos-Silva, U. Mandel, I. Jacobs, A. Dawnay, U. Menon, O. Blixt, Microarray Glycoprofiling of CA125 improves differential diagnosis of ovarian cancer, J Proteome Res, 12 (2013) 1408-1418. [8] Q.K. Li, E. Gabrielson, F. Askin, D.W. Chan, H. Zhang, Glycoproteomics using fluidbased specimens in the discovery of lung cancer protein biomarkers: Promise and challenge, PROTEOMICS - Clinical Applications, 7 (2013) 55-69. [9] T. Hanaoka, S. Sato, H. Tobita, T. Miyake, S. Ishihara, S. Akagi, Y. Amano, Y. Kinoshita, Clinical significance of the highly sensitive fucosylated fraction of $\alpha$-fetoprotein in patients with chronic liver disease, Journal of Gastroenterology and Hepatology, 26 (2011) 739-744.

[10] J.A. Loo, W. Yan, P. Ramachandran, D.T. Wong, Comparative human salivary and plasma proteomes, J Dent Res, 89 (2010) 1016-1023.

[11] B.L. Schulz, J. Cooper-White, C.K. Punyadeera, Saliva proteome research: current status and future outlook, Critical Reviews in Biotechnology, 33 (2013) 246-259.

407 [12] E. Topkas, P. Keith, G. Dimeski, J. Cooper-White, C. Punyadeera, Evaluation of saliva 408 collection devices for the analysis of proteins, Clinica Chimica Acta, 413 (2012) 1066-1070.

409 [13] Q. Wang, Q. Yu, Q. Lin, Y. Duan, Emerging salivary biomarkers by mass spectrometry, $410 \quad$ Clin Chim Acta, 438 (2015) 214-221.

411 [14] M. Yakob, L. Fuentes, M.B. Wang, E. Abemayor, D.T. Wong, Salivary biomarkers for 412 detection of oral squamous cell carcinoma - current state and recent advances, Curr Oral 413 Health Rep, 1 (2014) 133-141.

414 [15] K. Ohyama, M. Moriyama, J.N. Hayashida, A. Tanaka, T. Maehara, S. Ieda, S.

415 Furukawa, M. Ohta, Y. Imabayashi, S. Nakamura, Saliva as a potential tool for diagnosis of 416 dry mouth including Sjogren's syndrome, Oral Dis, 21 (2015) 224-231.

417 [16] J.Y. Foo, Y. Wan, B.L. Schulz, K. Kostner, J. Atherton, J. Cooper-White, G. Dimeski, 418 C. Punyadeera, Circulating fragments of N-terminal pro-B-type natriuretic peptides in plasma 419 of heart failure patients, Clin Chem, 59 (2013) 1523-1531.

420 [17] D.A. Ovchinnikov, Y. Wan, W.B. Coman, P. Pandit, J.J. Cooper-White, J.G. Herman, C. 421 Punyadeera, DNA Methylation at the Novel CpG Sites in the Promoter of MED15/PCQAP

422 Gene as a Biomarker for Head and Neck Cancers, Biomark Insights, 9 (2014) 53-60. 

neck cancers, Cell Oncol (Dordr), 37 (2014) 331-338. [19] P. Ramachandran, P. Boontheung, Y. Xie, M. Sondej, D.T. Wong, J.A. Loo, Identification of N-Linked Glycoproteins in Human Saliva by Glycoprotein Capture and Mass Spectrometry, Journal of Proteome Research, 5 (2006) 1493-1503. [20] H. Zhang, X.-j. Li, D.B. Martin, R. Aebersold, Identification and quantification of Nhydrazide chemistry, stable isotope labeling and mass spectrometry, Nat Biotech, 21 (2003) 660-666. [21] P. Ramachandran, P. Boontheung, E. Pang, W. Yan, D.T. Wong, J.A. Loo, Comparison of N-linked Glycoproteins in Human Whole Saliva, Parotid, Submandibular, and Sublingual Glandular Secretions Identified using Hydrazide Chemistry and Mass Spectrometry, Clin Proteomics, 4 (2008) 80-104. [22] S. Bandhakavi, S.K. Van Riper, P.N. Tawfik, M.D. Stone, T. Haddad, N.L. Rhodus, J.V. Carlis, T.J. Griffin, Hexapeptide libraries for enhanced protein PTM identification and relative abundance profiling in whole human saliva, J Proteome Res, 10 (2011) 1052-1061. [23] J.A. Ferreira, A.L. Daniel-da-Silva, R.M. Alves, D. Duarte, I. Vieira, L.L. Santos, R. Vitorino, F. Amado, Synthesis and optimization of lectin functionalized nanoprobes for the selective recovery of glycoproteins from human body fluids, Anal Chem, 83 (2011) 70357043.

[24] Y. Xu, U.M. Bailey, C. Punyadeera, B.L. Schulz, Identification of salivary Nglycoproteins and measurement of glycosylation site occupancy by boronate glycoprotein enrichment and liquid chromatography/electrospray ionization tandem mass spectrometry, Rapid Commun Mass Spectrom, 28 (2014) 471-482.

[25] D. Clark, L. Mao, Cancer biomarker discovery: lectin-based strategies targeting glycoproteins, Dis Markers, 33 (2012) 1-10.

[26] Y. Qin, Y. Zhong, M. Zhu, L. Dang, H. Yu, Z. Chen, W. Chen, X. Wang, H. Zhang, Z. Li, Age- and sex-associated differences in the glycopatterns of human salivary glycoproteins and their roles against influenza A virus, J Proteome Res, 12 (2013) 2742-2754.

[27] D. Loo, A. Jones, M.M. Hill, Lectin Magnetic Bead Array for Biomarker Discovery, Journal of Proteome Research, 9 (2010) 5496-5500.

[28] E. Choi, D. Loo, J.W. Dennis, C.A. O'Leary, M.M. Hill, High-throughput lectin magnetic bead array-coupled tandem mass spectrometry for glycoprotein biomarker discovery, ELECTROPHORESIS, 32 (2011) 3564-3575.

[29] Z.W. Lai, E.C. Nice, O. Schilling, Glycocapture-based proteomics for secretome analysis, Proteomics, 13 (2013) 512-525.

[30] S. Fanayan, M. Hincapie, W.S. Hancock, Using lectins to harvest the plasma/serum glycoproteome, Electrophoresis, 33 (2012) 1746-1754.

[31] T. Pfaffe, J. Cooper-White, P. Beyerlein, K. Kostner, C. Punyadeera, Diagnostic Potential of Saliva: Current State and Future Applications, Clinical Chemistry, 57 (2011) 675-687.

[32] M. Navazesh, S.K. Kumar, Measuring salivary flow: challenges and opportunities, J Am Dent Assoc, 139 Suppl (2008) 35S-40S.

[33] G. Candiano, M. Bruschi, L. Musante, L. Santucci, G.M. Ghiggeri, B. Carnemolla, P. Orecchia, L. Zardi, P.G. Righetti, Blue silver: A very sensitive colloidal Coomassie G-250 staining for proteome analysis, ELECTROPHORESIS, 25 (2004) 1327-1333. [34] K.A. Thomsson, B.L. Schulz, N.H. Packer, N.G. Karlsson, MUC5B glycosylation in human saliva reflects blood group and secretor status, Glycobiology, 15 (2005) 791-804. [35] P.B. Rasmussen, S. Bjorn, S. Hastrup, P.F. Nielsen, K. Norris, L. Thim, F.C. Wiberg, H. Flodgaard, Characterization of recombinant human HBP/CAP37/azurocidin, a pleiotropic 
473 mediator of inflammation-enhancing LPS-induced cytokine release from monocytes, FEBS 474 Lett, 390 (1996) 109-112.

475 [36] G.A. Turner, Haptoglobin. A potential reporter molecule for glycosylation changes in 476 disease, Adv Exp Med Biol, 376 (1995) 231-238.

477 [37] T. Ravnsborg, G. Houen, P. Hojrup, The glycosylation of myeloperoxidase, Biochimica 478 et biophysica acta, 1804 (2010) 2046-2053.

479 [38] E.S. Moh, M. Thaysen-Andersen, N.H. Packer, Relative versus absolute quantitation in 480 disease glycomics, Proteomics. Clinical applications, 9 (2015) 368-382.

481

482

483

484

485

486

487

488

489

490

491

492

493

494

495

496

497

498

499 
501 Carbohydrate binding specificities of lectins used in this study.

502

\begin{tabular}{|c|c|}
\hline Lectin & Sugar Specificity \\
\hline Aleuria aurantia (AAL) & Fuco1-6/3GIcNAc \\
\hline Bauhinia purpurea lectin (BPL) & Galß1-3GalNAc \\
\hline Concanavalin A (ConA) & $\alpha$-Man, $\alpha$-Glc, $\alpha$-GlcNAc \\
\hline Erythrina cristagalli agglutinin (ECA) & Galß4GIcNAc \\
\hline Jacalin (JAC) & 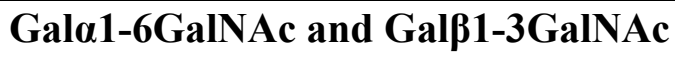 \\
\hline Narcissus pesudonarcissus lectin (NPL) & 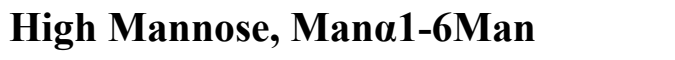 \\
\hline Sambucus nigra agglutinin (SNA) & Neu5Aco2-6Gal/GalNAc \\
\hline Wheat germ agglutinin (WGA) & GlcNAcß1-4GIcNAc and Neu5Ac \\
\hline
\end{tabular}


Table 2:

Key features of the optimized SaLeMBA method

\begin{tabular}{|l|l|l|}
\hline & LeMBA & SaLeMBA \\
\hline Biological sample used & Serum & Saliva \\
\hline $\begin{array}{l}\text { Amount of sample protein } \\
\text { per pull down }\end{array}$ & $50 \mu \mathrm{g}$ & $50 \mu \mathrm{g}$ \\
\hline $\begin{array}{l}\text { Average sample protein } \\
\text { concentrations ( } \pm \text { stdev) }\end{array}$ & $384.8 \pm$ \\
$9.2 \mu \mathrm{g} / \mu \mathrm{L}$ & $\begin{array}{l}2.11 \pm \\
0.035 \\
\mu \mathrm{g} / \mu \mathrm{L}\end{array}$ \\
\hline $\begin{array}{l}\text { Initial sample treatment } \\
\text { buffer (Denaturing Buffer) } \\
\text { volume }\end{array}$ & $15 \mu \mathrm{L}$ & $75 \mu \mathrm{L}$ \\
\hline $\begin{array}{l}\text { Sample to Lectin coupled } \\
\text { bead binding buffer volume }\end{array}$ & $85 \mu \mathrm{L}$ & $1425 \mu \mathrm{L}$ \\
\hline $\begin{array}{l}\text { Total volume (Denaturing } \\
\text { buffer + Binding buffer) }\end{array}$ & $100 \mu \mathrm{L}$ & $1500 \mu \mathrm{L}$ \\
\hline \begin{tabular}{l} 
Total incubation time \\
\hline
\end{tabular} & $1 \mathrm{~h} \mathrm{at} 4^{\circ} \mathrm{C}$ & $1 \mathrm{~h} \mathrm{at} 4^{\circ} \mathrm{C}$ \\
\hline
\end{tabular}


Table 3: Proteins robustly identified after saLeMBA enrichment.

\begin{tabular}{|c|c|c|c|c|c|c|}
\hline Identified Protein & $\begin{array}{l}\text { Accessio } \\
\text { n } \\
\text { number }\end{array}$ & AAL & BPL & ECA & NPL & SNA \\
\hline $\begin{array}{l}\text { Actin, cytoplasmic } \\
2\end{array}$ & P63261 & $\begin{array}{l}4.67 \pm \\
1.15\end{array}$ & & & & \\
\hline $\begin{array}{l}\text { Alpha-2- } \\
\text { macroglobulin }\end{array}$ & P04745 & & & & $\begin{array}{l}3.67 \pm \\
1.53\end{array}$ & \\
\hline $\begin{array}{l}\text { Alpha-2- } \\
\text { macroglobulin-like } \\
\text { protein } 1\end{array}$ & A8K2U0 & & & & $\begin{array}{l}19.33 \pm \\
1.15\end{array}$ & \\
\hline Alpha-amylase 1 & P04745 & $\begin{array}{l}49.00 \pm \\
2.65\end{array}$ & $\begin{array}{l}20.67 \\
\pm 8.39\end{array}$ & $\begin{array}{l}18.33 \pm \\
8.62\end{array}$ & $\begin{array}{l}46.27 \pm \\
3.21\end{array}$ & $\begin{array}{l}33.67 \pm \\
12.74\end{array}$ \\
\hline Annexin A1 & P04083 & $\begin{array}{l}8.00 \pm \\
3.00\end{array}$ & $\begin{array}{l}11.67 \\
\pm 2.08\end{array}$ & $\begin{array}{l}5.67 \pm \\
3.21\end{array}$ & $\begin{array}{l}7.67 \pm \\
1.53\end{array}$ & $9.67 \pm 3.06$ \\
\hline Azurocidin & P20160 & $\begin{array}{l}6.67 \pm \\
1.53\end{array}$ & & & & \\
\hline $\begin{array}{l}\text { Beta-2- } \\
\text { glycoprotein } 1\end{array}$ & P02749 & & & & & $1.67 \pm 0.58$ \\
\hline $\begin{array}{l}\text { BPI fold- } \\
\text { containing family } \\
\text { A member } 2\end{array}$ & Q8N4F0 & $\begin{array}{l}5.53 \pm \\
1.15\end{array}$ & & & & \\
\hline $\begin{array}{l}\text { BPI fold- } \\
\text { containing family } \\
\text { B member } 2\end{array}$ & Q96DR5 & $\begin{array}{l}7.67 \pm \\
0.58\end{array}$ & & & $\begin{array}{l}7.00 \pm \\
1.00\end{array}$ & $6.33 \pm 1.53$ \\
\hline $\begin{array}{l}\text { Carbonic } \\
\text { anhydrase } 6\end{array}$ & P23280 & $\begin{array}{l}8.33 \pm \\
0.58\end{array}$ & $\begin{array}{l}2.33 \pm \\
0.58\end{array}$ & & $\begin{array}{l}10.67 \pm \\
2.52\end{array}$ & $11.67 \pm 3.06$ \\
\hline Cathepsin G & P08311 & $\begin{array}{l}3.00 \pm \\
1.00\end{array}$ & & & $\begin{array}{l}6.00 \pm \\
1.00\end{array}$ & $5.33 \pm 1.15$ \\
\hline Complement C3 & P01024 & & & & $\begin{array}{l}2.67 \pm \\
0.58\end{array}$ & \\
\hline Cornulin & Q9UBG3 & $\begin{array}{l}3.33 \pm \\
2.08\end{array}$ & $\begin{array}{l}2.67 \pm \\
0.58\end{array}$ & & $\begin{array}{l}6.00 \pm \\
1.00\end{array}$ & \\
\hline
\end{tabular}




\begin{tabular}{|c|c|c|c|c|c|c|}
\hline Cystatin-S & P01036 & $\begin{array}{l}9.00 \pm \\
2.00\end{array}$ & & & $\begin{array}{l}5.33 \pm \\
0.58\end{array}$ & \\
\hline $\begin{array}{l}\text { Cytoplasmic } \\
\text { dynein } 1 \text { heavy } \\
\text { chain } 1\end{array}$ & Q14204 & & $\begin{array}{l}1.67 \pm \\
0.58\end{array}$ & & & \\
\hline $\begin{array}{l}\text { Deleted in } \\
\text { malignant brain } \\
\text { tumors } 1 \text { protein }\end{array}$ & $\begin{array}{l}\text { Q9UGM } \\
3\end{array}$ & $\begin{array}{l}15.00 \pm \\
2.52\end{array}$ & $\begin{array}{l}14.33 \\
\pm 0.58\end{array}$ & $\begin{array}{l}1.33 \pm \\
0.58\end{array}$ & $\begin{array}{l}8.00 \pm \\
2.00\end{array}$ & $5.33 \pm 1.21$ \\
\hline $\begin{array}{l}\text { Galectin-3-binding } \\
\text { protein }\end{array}$ & Q08380 & $\begin{array}{l}5.67 \pm \\
0.58\end{array}$ & & & $\begin{array}{l}2.00 \pm \\
0.00\end{array}$ & \\
\hline $\begin{array}{l}\text { Glyceraldehyde-3- } \\
\text { phosphate } \\
\text { dehydrogenase }\end{array}$ & P04406 & & & & $\begin{array}{l}2.33 \pm \\
0.58\end{array}$ & \\
\hline Haptoglobin & P00738 & & & & & $3.33 \pm 1.53$ \\
\hline $\begin{array}{l}\text { Heat shock } \\
\text { cognate } 71 \text { kDa } \\
\text { protein }\end{array}$ & P11142 & & $\begin{array}{l}3.33 \pm \\
0.58\end{array}$ & & & \\
\hline Hemopexin & P02790 & & & & & $1.67 \pm 0.58$ \\
\hline Histatin-1 & P15515 & $\begin{array}{l}1.67 \pm \\
0.58\end{array}$ & & & & \\
\hline $\begin{array}{l}\text { Ig alpha-1 chain } \mathrm{C} \\
\text { region }\end{array}$ & P01876 & $\begin{array}{l}23.00 \pm \\
4.36\end{array}$ & $\begin{array}{l}10.33 \\
\pm 1.15\end{array}$ & $\begin{array}{l}7.33 \pm \\
2.89\end{array}$ & $\begin{array}{l}32.67 \pm \\
0.58\end{array}$ & $22.00 \pm 3.00$ \\
\hline $\begin{array}{l}\text { Ig gamma-1 chain } \\
\text { C region }\end{array}$ & P01857 & $\begin{array}{l}4.00 \pm \\
0.00\end{array}$ & $\begin{array}{l}1.67 \pm \\
0.58\end{array}$ & & $\begin{array}{l}10.00 \pm \\
0.00\end{array}$ & $6.00 \pm 0.00$ \\
\hline $\begin{array}{l}\text { Ig gamma-2 chain } \\
\text { C region }\end{array}$ & P01859 & $\begin{array}{l}5.00 \pm \\
1.00\end{array}$ & & & & \\
\hline $\begin{array}{l}\text { Ig heavy chain } \mathrm{V} \text { - } \\
\text { III region BRO }\end{array}$ & P01766 & $\begin{array}{l}2.67 \pm \\
0.58\end{array}$ & & & $\begin{array}{l}3.00 \pm \\
0.00\end{array}$ & $2.33 \pm 0.58$ \\
\hline $\begin{array}{l}\text { Ig kappa chain } \mathrm{C} \\
\text { region }\end{array}$ & P01834 & $\begin{array}{l}15.00 \pm \\
1.00\end{array}$ & $\begin{array}{l}7.00 \pm \\
1.00\end{array}$ & $\begin{array}{l}14.33 \pm \\
7.23\end{array}$ & $\begin{array}{l}17.33 \pm \\
1.53\end{array}$ & $13.00 \pm 3.61$ \\
\hline $\begin{array}{l}\text { Ig kappa chain V- } \\
\text { II region RPMI } \\
6410\end{array}$ & P06310 & $\begin{array}{l}1.00 \pm \\
0.00\end{array}$ & & & & \\
\hline
\end{tabular}




\begin{tabular}{|c|c|c|c|c|c|c|}
\hline $\begin{array}{l}\text { Ig lambda-2 chain } \\
\text { C regions }\end{array}$ & P0CG05 & $\begin{array}{l}8.00 \pm \\
1.73\end{array}$ & & & & \\
\hline $\begin{array}{l}\text { Ig lambda-7 chain } \\
\text { C region }\end{array}$ & A0M8Q6 & & & & $\begin{array}{l}3.33 \pm \\
0.58\end{array}$ & \\
\hline $\begin{array}{l}\text { Ig mu chain } \mathrm{C} \\
\text { region }\end{array}$ & P01871 & $\begin{array}{l}8.67 \pm \\
1.53\end{array}$ & & & $\begin{array}{l}17.67 \pm \\
3.21\end{array}$ & $6.33 \pm 1.15$ \\
\hline $\begin{array}{l}\text { Immunoglobulin } \mathbf{J} \\
\text { chain }\end{array}$ & P01591 & & & & & $2.67 \pm 0.58$ \\
\hline Integrin alpha-M & P11215 & & & & $\begin{array}{l}12.33 \pm \\
2.52\end{array}$ & \\
\hline Kallikrein-1 & P06870 & $\begin{array}{l}3.67 \pm \\
0.58\end{array}$ & & & & $3.00 \pm 1.00$ \\
\hline $\begin{array}{l}\text { Keratin, type I } \\
\text { cytoskeletal } 13\end{array}$ & P13646 & & & & & $26.33 \pm 6.03$ \\
\hline $\begin{array}{l}\text { Keratin, type I } \\
\text { cytoskeletal } 9\end{array}$ & P35527 & $\begin{array}{l}17.67 \pm \\
1.53\end{array}$ & $\begin{array}{l}7.67 \pm \\
5.50\end{array}$ & $\begin{array}{l}14.67 \pm \\
7.09\end{array}$ & $\begin{array}{l}5.67 \pm \\
1.15\end{array}$ & \\
\hline $\begin{array}{l}\text { Keratin, type II } \\
\text { cytoskeletal } 1\end{array}$ & P04264 & & & $\begin{array}{l}18.33 \pm \\
3.51\end{array}$ & $\begin{array}{l}15.33 \pm \\
2.31\end{array}$ & \\
\hline $\begin{array}{l}\text { Keratin, type II } \\
\text { cytoskeletal } 4\end{array}$ & P19013 & & $\begin{array}{l}19.67 \\
\pm 5.13\end{array}$ & $\begin{array}{l}20.67 \pm \\
6.43\end{array}$ & & \\
\hline $\begin{array}{l}\text { Keratin, type II } \\
\text { cytoskeletal } 6 A\end{array}$ & P02538 & & & & $\begin{array}{l}11.67 \pm \\
3.79\end{array}$ & \\
\hline Lactoperoxidase & P22079 & $\begin{array}{l}4.33 \pm \\
0.58\end{array}$ & & & $\begin{array}{l}12.33 \pm \\
1.15\end{array}$ & \\
\hline Lactotransferrin & P02788 & $\begin{array}{l}37.67 \pm \\
0.58\end{array}$ & $\begin{array}{l}10.00 \\
\pm 2.00\end{array}$ & $\begin{array}{l}30.00 \pm \\
6.56\end{array}$ & $\begin{array}{l}31.33 \pm \\
5.69\end{array}$ & $42.67 \pm 2.08$ \\
\hline Lysozyme C & P61626 & $\begin{array}{l}1.33 \pm \\
0.58\end{array}$ & $\begin{array}{l}1.67 \pm \\
0.58\end{array}$ & & $\begin{array}{l}1.67 \pm \\
0.58\end{array}$ & \\
\hline Mucin-5B & Q9HC84 & $\begin{array}{l}59.00 \pm \\
4.36\end{array}$ & $\begin{array}{l}11.00 \\
\pm 4.58\end{array}$ & & $\begin{array}{l}25.00 \pm \\
2.65\end{array}$ & $56.67 \pm 2.52$ \\
\hline Mucin-7 & Q8TAX7 & $\begin{array}{l}5.00 \pm \\
2.00\end{array}$ & $\begin{array}{l}8.00 \pm \\
2.65\end{array}$ & $\begin{array}{l}2.33 \pm \\
0.58\end{array}$ & $\begin{array}{l}3.33 \pm \\
1.53\end{array}$ & \\
\hline
\end{tabular}




\begin{tabular}{|c|c|c|c|c|c|c|}
\hline Myeloblastin & P24158 & $\begin{array}{l}2.33 \pm \\
0.58\end{array}$ & & & & \\
\hline Myeloperoxidase & P05164 & & & & $\begin{array}{l}32.33 \pm \\
2.52\end{array}$ & \\
\hline $\begin{array}{l}\text { Neuroblast } \\
\text { differentiation- } \\
\text { associated protein } \\
\text { AHNAK }\end{array}$ & Q09666 & & & & & $2.00 \pm 0.00$ \\
\hline $\begin{array}{l}\text { Neutrophil } \\
\text { defensin } 3\end{array}$ & P59666 & & & $\begin{array}{l}2.00 \pm \\
0.00\end{array}$ & & \\
\hline $\begin{array}{l}\text { Polymeric } \\
\text { immunoglobulin } \\
\text { receptor }\end{array}$ & P01833 & $\begin{array}{l}34.67 \pm \\
3.06\end{array}$ & $\begin{array}{l}13.00 \\
\pm 1.73\end{array}$ & & $\begin{array}{l}40.33 \pm \\
4.73\end{array}$ & $27.67 \pm 2.89$ \\
\hline Profilin-1 & P07737 & $\begin{array}{l}3.00 \pm \\
1.00\end{array}$ & & & $\begin{array}{l}2.67 \pm \\
0.58\end{array}$ & \\
\hline $\begin{array}{l}\text { Prolactin- } \\
\text { inducible protein }\end{array}$ & P12273 & $\begin{array}{l}15.67 \pm \\
3.51\end{array}$ & $\begin{array}{l}5.00 \pm \\
1.00\end{array}$ & $\begin{array}{l}7.67 \pm \\
3.21\end{array}$ & $\begin{array}{l}11.00 \pm \\
1.00\end{array}$ & $11.67 \pm 3.21$ \\
\hline Protein S100-A8 & P05109 & $\begin{array}{l}4.00 \pm \\
0.00\end{array}$ & $\begin{array}{l}3.33 \pm \\
0.58\end{array}$ & $\begin{array}{l}3.33 \pm \\
1.15\end{array}$ & $\begin{array}{l}4.33 \pm \\
0.58\end{array}$ & $4.00 \pm 1.00$ \\
\hline Protein S100-A9 & P06702 & $\begin{array}{l}2.67 \pm \\
0.58\end{array}$ & & & & \\
\hline $\begin{array}{l}\text { Protein-glutamine } \\
\text { gamma- } \\
\text { glutamyltransferas } \\
\text { e E }\end{array}$ & Q08188 & $\begin{array}{l}2.67 \pm \\
0.58\end{array}$ & & & $\begin{array}{l}3.67 \pm \\
1.15\end{array}$ & \\
\hline Serotransferrin & P02787 & $\begin{array}{l}5.33 \pm \\
1.53\end{array}$ & & & $\begin{array}{l}3.00 \pm \\
1.00\end{array}$ & $6.33 \pm 1.53$ \\
\hline Serum albumin & P02768 & $\begin{array}{l}14.00 \pm \\
0.00\end{array}$ & & & $\begin{array}{l}5.33 \pm \\
1.15\end{array}$ & \\
\hline $\begin{array}{l}\text { Small proline-rich } \\
\text { protein } 2 \mathrm{G}\end{array}$ & Q9BYE4 & & & $\begin{array}{l}1.67 \pm \\
1.15\end{array}$ & & \\
\hline $\begin{array}{l}\text { Small proline-rich } \\
\text { protein } 3\end{array}$ & Q9UBC9 & $\begin{array}{l}2.33 \pm \\
0.58\end{array}$ & $\begin{array}{l}3.00 \pm \\
1.73\end{array}$ & $\begin{array}{l}3.67 \pm \\
1.15\end{array}$ & $\begin{array}{l}3.33 \pm \\
0.58\end{array}$ & \\
\hline
\end{tabular}




\begin{tabular}{|l|l|l|l|l|l|l|}
\hline Statherin & P02808 & & & & & $2.00 \pm 0.00$ \\
\hline Transcobalamin-1 & P20061 & & & & & $1.00 \pm 0.00$ \\
\hline Transketolase & P29401 & & & & $\begin{array}{l}7.33 \pm \\
0.58\end{array}$ & \\
\hline $\begin{array}{l}\text { UPF0762 protein } \\
\text { C6orf58 }\end{array}$ & Q6P552 & $\begin{array}{l}4.33 \pm \\
0.58\end{array}$ & & & $2.00 \pm$ & $3.67 \pm 1.53$ \\
\hline $\begin{array}{l}\text { Zinc-alpha-2- } \\
\text { glycoprotein }\end{array}$ & P25311 & $\begin{array}{l}16.67 \pm \\
1.15\end{array}$ & & & $5.00 \pm$ & $14.67 \pm 0.58$ \\
\hline $\begin{array}{l}\text { Zymogen granule } \\
\text { protein 16 } \\
\text { homolog B }\end{array}$ & Q96DA0 & $\begin{array}{l}17.00 \pm \\
3.61\end{array}$ & $\begin{array}{l}8.00 \pm \\
1.00\end{array}$ & & $\begin{array}{l}17.00 \pm \\
0.00\end{array}$ & $12.67 \pm 0.58$ \\
\hline
\end{tabular}

Accession numbers are from Swiss-Prot. The table shows the average number of spectra \pm standard deviation. 
